Scotch ones, or that my experiments were conducted under circumstances materially different from those under which the experiments of the Edinburgh Committee were carried on, I could not decide; but it was indubitable that our results differed to a very serious degree. A new set of experiments which was at once undertaken gave perfect distinctness to the divergence of our results.

TABLE IX.-Showing the Minimum Fatal Dose of Chloral-Iydrate in Rabbits.

\begin{tabular}{|c|c|c|c|}
\hline No. & $\begin{array}{l}\text { Weight of } \\
\text { Rabbit. }\end{array}$ & $\begin{array}{l}\text { Dose of Chloral- } \\
\text { Hydrate in grs. }\end{array}$ & Result. \\
\hline $\begin{array}{l}66 \\
67 \\
68 \\
69 \\
70 \\
71 \\
72 \\
73 \\
74 \\
75 \\
76\end{array}$ & $\begin{array}{l}3 \text { lbs. } 2 \mathrm{oz} . \\
3 \text { lbs. } 11 \mathrm{oz} . \\
4 \text { lbs. } 2 \mathrm{oz} \\
3 \text { lbs. } 1 \frac{1}{2} \mathrm{oz} . \\
3 \text { lbs. } 3 \mathrm{oz} \\
3 \text { lbs. } 10 \mathrm{oz} \\
2 \text { lbs. } 1 \frac{1}{2} \mathrm{oz} . \\
2 \text { lbs. } 12 \frac{1}{2} \mathrm{oz} . \\
3 \text { lbs. } 1 \mathrm{oz} . \\
3 \text { lbs. } 2 \mathrm{oz} \\
2 \text { lbs. } 14 \mathrm{oz} .\end{array}$ & $\begin{array}{l}30 \\
30 \\
35 \\
35 \\
36 \\
40 \\
40 \\
40 \\
42 \\
46 \\
46\end{array}$ & $\begin{array}{l}\text { Recovery } \\
\quad, \text {, } \\
\text { Death in four hours } \\
\text { Recovery } \\
\text { Recovery } \\
\text { Death in two hours } \\
\text { Death in two hours and twenty minutes } \\
\text { Death in three hours and ten minutes } \\
\text { Death in one hour and twenty-five min. } \\
\text { Death in one hour and fifty-four minutes }\end{array}$ \\
\hline
\end{tabular}

Instead of finding, as the Edinburgh Committee did, that seven grains of chloral hydrate per pound of body weight was fatal in rabbits, I satisfied myself that nothing less than twelve grains per pound of body weight can be regarded as a fatal proportion of that drug in these animals. The only explanation of this discrepancy which I can offer is, that perhaps temperature had something to do with it. The room in which I worked had usually a temperature of about 56 degs. Fahrenheit's scale, and the rabbits, after having had chloral given to them, were always placed near a warm fire, and on cotton-wool. If the Edinburgh Committee maintained the heat of the rabbits upon which they experimented less carefully, it is conceivable that a smaller dose of chloral-hydrate would suffice to extinguish life; for Dr. Lauder Brunton has shown that warmth is most potent in hastening recovery from the effects of chloral hydrate, and in preventing death after an overdose. The chloral-hydrate used in my experiments was supplied by Messrs. Harvey and Reynolds of Leeds, and Messrs. Davy, Yates, and Routledge of London, and the solutions were prepared with scrupulous care.

To determine whether picrotoxine was really antagonistic to chloralhydrate, and, if so, to what extent that antagonism extended, another set of experiments was clearly necessary, and these were forthwith undertaken; the minimum fatal dose of chloral-hydrate being now taken as twelve grains to each pound of body-weight.

TABLE X.-Shoving the Effects of Small Doses of Picrotoxine injected with Fatal Doses of Chloral-IIydrate.

\begin{tabular}{|c|c|c|c|c|c|}
\hline No. & $\begin{array}{l}\text { Weight of } \\
\text { Rabbit. }\end{array}$ & 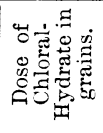 & 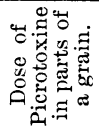 & Effects. & Result. \\
\hline $\begin{array}{l}77 \\
78 \\
79 \\
80 \\
81 \\
82 \\
83 \\
84 \\
85 \\
86\end{array}$ & $\begin{array}{l}3 \text { lbs. } 3 \mathrm{oz} . \\
3 \text { lbs. } 3 \frac{1}{2} \mathrm{oz} . \\
3 \text { lbs. } 2 \mathrm{oz} . \\
3 \text { lbs. } 3 \mathrm{oz} . \\
2 \text { lbs. } 14 \mathrm{oz} . \\
3 \text { lbs. } 1 \mathrm{oz} . \\
3 \text { lbs. } \\
2 \text { lbs. } 13 \mathrm{oz} . \\
3 \text { lbs. } 1 \mathrm{oz} . \\
3 \text { lbs. } 4 \mathrm{oz} .\end{array}$ & $\begin{array}{l}36 \\
37 \\
38 \\
38 \\
39 \\
10 \\
40 \\
41 \\
41 \\
42\end{array}$ & $\begin{array}{l}1-30 \text { th } \\
1-20 \text { th } \\
1-40 \text { th } \\
1-20 \text { th } \\
1-40 \text { th } \\
1-30 \text { th } \\
1-40 \text { th } \\
1-30 \text { th } \\
1-40 \text { th } \\
1-20 \text { th }\end{array}$ & $\begin{array}{l}\text { Deep sleep } \\
\text { Restlessness, sleep } \\
\text { Deep sleep } \\
\text { Disturbed sleep } \\
\text { Deep sleep } \\
\text { Disturbed sleep } \\
\text { Deep sleep } \\
\quad \text {," } \\
\quad \text {," }\end{array}$ & $\begin{array}{l}\text { Recovery } \\
\quad, " \\
\text { Death } \\
\text { Recovery } \\
\text { Death } \\
\quad, \\
\text { ", } \\
\text { ", }\end{array}$ \\
\hline
\end{tabular}

These experiments made it apparent that the antagonism of picrotoxine to chloral-hydrate in rabbits is by no means so great as it was at first thought to be. Whenever the dose of the latter exceeded by four grains the minimum fatal amount, picrotoxine failed to avert death. Given in large amount, the chloral seemed to take possession of the nervous system so completely that it could not be dislodged by moderate doses of picrotoxine. And the issue of one experiment, in which a highly poisonous dose of picrotoxine, one-fourth of a grain, was given, after a fatal dose of chloral-hydrate-forty grains, did not encourage the hope that picrotoxine, in any quantity, could be employed to counteract large doses of chloral. The rabbit died, without having suffered from convulsions, much more rapidly than it would have done if left to sink under chloral poisoning. And yet, that there is a certain degree of antagonism exerted by picrotoxine against the toxic effects of chloral hydrate, is unmistakable. It does secure recovery in some cases, in which, but for its influence, death would almost inevitably ensue; and even, when it is powerless to save life, it notably controls symptoms. It rouses the cerebral centres from time to time, from that state of torpor which chloral spreads over them. It limits the depth of the chloral narcosis, and breaks in upon it occasionally by intervals of semi-wakefulness, in which there are various spontaneous movements. It diminishes the hyperæsthesia which chloral sets up; and it prevents, to a considerable degree, that gradual production of slowness of the respiration, and that fall of temperature, which chloral constantly induces. The following table exhibits its action in keeping up the respiratory movements and the animal heat, in contrast with the unmodified effect of chloral upon these.

TABLE XI.-Shoving the Effects of Chloral-Hydrate in reducing Temperature, ant the Number of Respirations and the Effects of Picrotoxine in partially preventing that reduction.

\begin{tabular}{|c|c|c|c|c|}
\hline \multirow{2}{*}{ 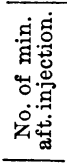 } & \multicolumn{2}{|c|}{$\begin{array}{l}\text { No. 87. Rabbit weighing } 3 \text { lbs. } 1 \frac{1}{2} \text { oz., } \\
\text { injected with } 35 \text { grs. of Chloral. } \\
\text { Hydrate alone. }\end{array}$} & \multicolumn{2}{|c|}{$\begin{array}{c}\text { No. 88. Rabbit weighing } 2 \text { lbs. } 14 \frac{1}{2} 07 . \\
\text { injected with } 35 \text { grs. of Chloral- } \\
\text { Hydrate and } 1-25 \text { th of a gr. } \\
\text { of Picrotoxine. }\end{array}$} \\
\hline & Temperature. & Respirations. & Temperature. & Respirations. \\
\hline $\begin{array}{r}5 \\
10 \\
20 \\
50 \\
60 \\
90 \\
120 \\
150 \\
180 \\
190 \\
210 \\
230 \\
240 \\
250 \\
270 \\
300 \\
320\end{array}$ & $\begin{array}{r}100.4 \\
99.6 \\
98.6 \\
97.4 \\
96.8 \\
95.5 \\
91.9 \\
94.3 \\
92.0 \\
90.8 \\
89.5 \\
85.8 \\
\text { Died. } \\
= \\
= \\
- \\
-\end{array}$ & $\begin{array}{l}60 \\
57 \\
50 \\
43 \\
40 \\
33 \\
27 \\
27 \\
21 \\
21 \\
20 \\
16 \\
- \\
= \\
= \\
-\end{array}$ & $\begin{array}{c}100.0 \\
99.1 \\
98.4 \\
98.2 \\
98.4 \\
98.4 \\
97.6 \\
96.6 \\
95.0 \\
95.4 \\
95.0 \\
94.5 \\
93.0 \\
90.8 \\
92.2 \\
94.3 \\
\text { Ultimately }\end{array}$ & $\begin{array}{c}72 \\
72 \\
68 \\
68 \\
65 \\
65 \\
61 \\
61 \\
51 \\
52 \\
66 \\
60 \\
60 \\
60 \\
60 \\
60 \\
\text { e recovered. }\end{array}$ \\
\hline
\end{tabular}

[To be continued.]

\section{CROUP AND DIPHTHERIA.}

By WILLIAM CUMMING, M.D., Edinburgh.

THE question as to the identity of membranous croup and diphtheria is worthy of the attention it has recently received; but, I confess, I have some difficulty in understanding how the two diseases can be ranged under the same category. Many years ago, I saw a large number of cases of membranous croup, and its characters were of the most pronounced kind.

I. The type was sthenic. 2. The exciting cause was atmospheric, i.e., cold and damp. 3. The treatment most successful in my hands, was antiphlogistic, viz., tartar emetic in frequent and nauseating doses. 4. It was non-contagious. I never saw two cases in one family either occurring simultaneously or in immediate succession. 5. It was never followed by paralysis or other consequences affecting the nervous system. 6. It was limited to a certain age; never in my experience occurring after twelve years of age. 7. The membrane, as ascertained by post mortem examinations (which were sufficiently frequent), was firm, tough, tense, and of a light kid colour, and was strictly limited to the laryngo tracheal tract, at least in its upper part, though it not unfrequently passed downwards into the bronchi in the form of plastic bronchitis. The disease never invaded the pharynx, fauces, or nose.

All who have seen much of diphtheria cannot fail to remark how totally different pronounced cases of it are. $\mathbf{r}$. The type is asthenic. 2. The exciting cause is septic. 3. The treatment is antiseptic, nourishing, and stimulating. 4. It is markedly contagious, and, unless the most stringent precautions are taken, attacks, and proves fatal to other members of the family, or those in direct contact with it. 5 . Nervous symptoms, and especially paralysis, are not unfrequent consequences, and are always to be feared. 6. It has no respect for age. 7. The membrane is ash grey, friable, in many cases almost pultaceous, and generally soft. It is seldom limited to the laryngo tracheal tract, but as frequently as not extends to the pharynx, fauces, and nose, and often begins there, passing downwards, which membranous croup never does.

Typhus and typhoid fever are recognised now by sufficiently distinctive characters, but they are, in my opinion, not more, or indeed so distinct, as are membranous croup and diphtheria.

A Cottage Infirmary is to be built at Mold. The Duke of Westminster, Mr. P. B. D. Cooke, and Mr. W. B. Buddicom, have each subscribed $£ \mathrm{I}$ (OO, and others smaller amounts, making in the aggregate about $€ 500$. 